\title{
16. HYDROTHERMAL ALTERATION OF PERIDOTITE FROM THE GALICIA MARGIN, IBERIAN PENINSULA ${ }^{1}$
}

\author{
Karen L. Kimball, Rensselaer Polytechnic Institute, Troy, New York \\ and \\ Cynthia A. Evans, ${ }^{2}$ Lamont-Doherty Geological Laboratory, Palisades, New York
}

\begin{abstract}
The Galicia margin lies northwest of the Iberian Peninsula and is a passive ocean margin with thin sedimentary cover. Altered peridotite was recovered from ODP Site 637, on the north-trending ridge at the western edge of the margin, near the oceanic/continental crust boundary.

The altered ultramafics were originally clinopyroxene-rich upper mantle harzburgites and are now extensively serpentinized $(>85 \%)$ and cut by very late-stage carbonate veins. Despite pervasive late, low-temperature alteration, evidence of early, high-temperature alteration remains. Alteration is apparent as (1) amphibole rims on clinopyroxene $\left(>800^{\circ} \mathrm{C}\right)$, (2) hornblende + tremolite $\left(450^{\circ}\right.$ to $\left.800^{\circ} \mathrm{C}\right)$, (3) breakdown of hornblende to form tremolite + chlorite $\left(<450^{\circ} \mathrm{C}\right)$, (4) zoned Cr-spinels, (5) hydration of orthopyroxene and olivine to serpentine, (6) serpentine veins, (7) replacement of pyroxene and olivine by calcite, and (8) calcite veins and vugs.

Both the relict igneous and the high-temperature alteration minerals (amphiboles) show evidence of brittle deformation. Subsequent low-temperature alteration veins and minerals are deformed only in faulted and brecciated zones. This textural evidence suggests that the low-temperature alteration occurred after emplacement of the ultramafics at the surface. Serpentine fills tension fractures in orthopyroxene, and both serpentine and calcite fill tension cracks in olivine.

The high-temperature alterations in these samples are similar to those found in oceanic fracture zone and ophiolite ultramafics. This widespread occurrence of high-temperature alteration suggests that hot fluids were pervasive in these ultramafic blocks.

Localization of high-temperature alteration close to large carbonate veins suggests channelization of the late, lowtemperature fluids. Earlier hydrations (e.g., high-temperature alterations and serpentinization) were pervasive.
\end{abstract}

\section{INTRODUCTION}

The Galicia margin, northwest of the Iberian Peninsula, is a passive ocean margin with thin sedimentary cover (Fig. 1). Ocean Drilling Program (ODP) Leg 103 recovered altered peridotite at Site 637 on the north-trending ridge at the western edge of the margin, near the oceanic/continental crust boundary (see "Site 637" chapter; Shipboard Scientific Party, 1987).

The altered ultramafic rocks that were recovered were originally clinopyroxene-rich upper mantle harzburgites, now extensively serpentinized $(>85 \%)$ and cut by very late-stage carbonate veins. Despite pervasive late, low-temperature alteration, evidence of early, high-temperature alteration remains.

These altered abyssal ultramafic rocks, recovered by drilling, represent the first opportunity to study lithologic, compositional, and structural variability in a continuous core sample. Analysis of the spatial relationships among alteration mineralogies and textures is not possible in samples recovered by dredging. This report will describe, in detail, the high-temperature $\left(>300^{\circ} \mathrm{C}\right)$ alteration mineralogies and textures present in these samples. Suggestions about the interpretations and significance of these observations will be made in light of the spatial relationships recorded. Lower temperature alterations such as calcite and serpentine will be discussed only as they relate to the high-temperature alterations. Low-temperature alteration of the Galicia margin peridotites is discussed in Evans and Baltuck (this volume) and Agrinier et al. (this volume).

${ }^{1}$ Boillot, G., Winterer, E. L., et al., 1988. Proc. ODP, Sci. Results, 103: College Station,TX (Ocean Drilling Program).

2 Present address: CA8, NASA, Johnson Space Center, Houston, TX 77058.

\section{Regional Setting of the Galicia Margin Peridotite}

Coring at Hole 637A recovered $35.9 \mathrm{~m}$ of serpentinized peridotite (from $70 \mathrm{~m}$ of cored rock) from beneath $212 \mathrm{~m}$ of Miocene-Pliocene sediments. Drilling ended in an apparent fault zone. The peridotite ridge is interpreted as probable upwelling of upper mantle beneath an incipient ocean basin (Evans and Girardeau, this volume; Girardeau et al., this volume).

The Galicia margin peridotite is composed of several rock types, including clinopyroxene-rich spinel harzburgite and lherzolite and plagioclase-bearing peridotite. The mineral compositions and abundances suggest that although the Galicia margin peridotite is similar to other oceanic peridotites, it is less depleted in basaltic components than other North Atlantic peridotites (Evans and Girardeau, this volume). Whole-rock chemistry indicates large abundances of the magmaphilic elements $\mathrm{Na}, \mathrm{Al}$, and $\mathrm{Ti}$, suggesting that the Galicia margin peridotite experienced, at most, small amounts of partial melting. The undepleted compositions are consistent with emplacement of the peridotite during incipient rifting of the ocean basin, before a true spreading center was established (Evans and Girardeau, this volume).

The modal minerals in the peridotite vary from $70 \%$ to $90 \%$ olivine, $8 \%$ to $18 \%$ orthopyroxene, $2 \%$ to $7 \%$ clinopyroxene, and $0.5 \%$ to $2 \%$ chromium spinel. These relative modal amounts can vary within 15 to $20 \mathrm{~cm}$ downhole. Plagioclase is present in several bands within the peridotite, and although typically present in minor amounts $(0.5 \%$ to $1.0 \%)$, it can constitute $2 \%$ to $3 \%$ of the rock in the bands.

Strong foliation is present in some parts of the cores, particularly within orthopyroxene-rich bands. Spinel-rich layers also define foliation. Most clinopyroxene grains are equant. The structures are discussed in detail in Girardeau et al. (this volume). 


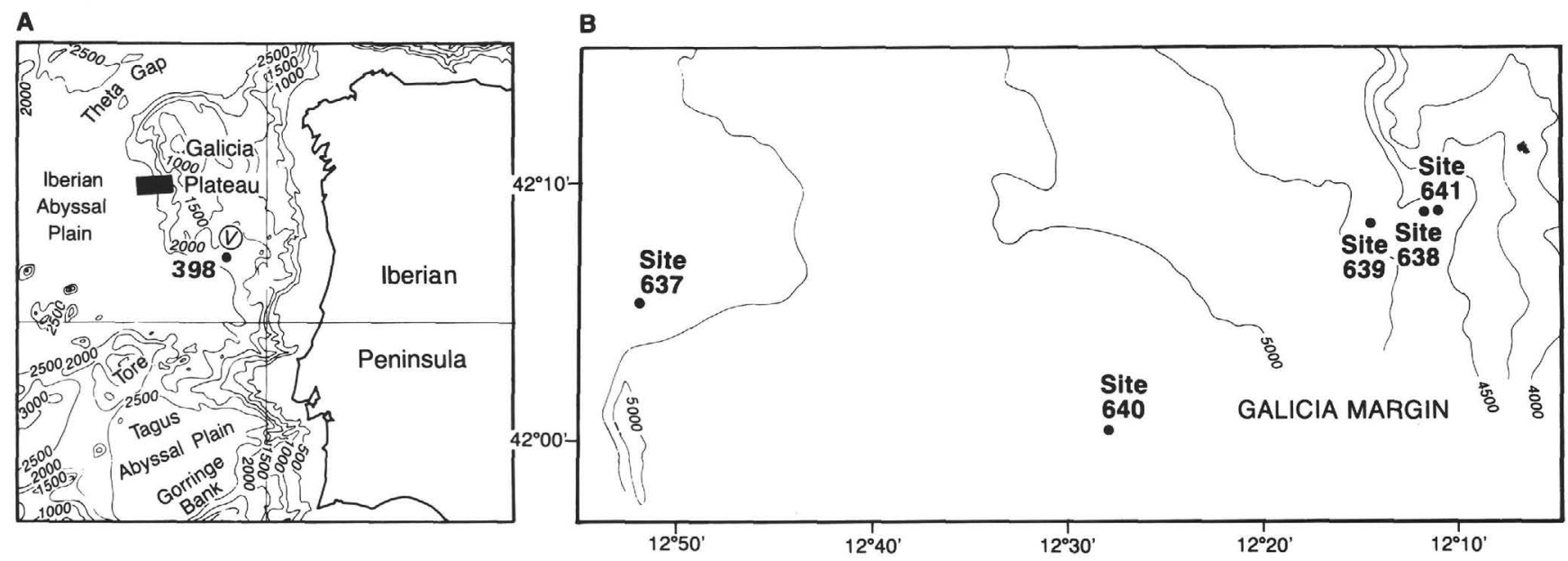

Figure 1. Map showing the location of the Galicia margin peridotite (after the diagram by the shipboard scientific party; Boillot, Winterer, et al., 1987). A. Bathymetric map showing the Galicia margin. Contour interval is $500 \mathrm{~m}$. The rectangle shows the extent of area in Figure 1B. B. Map showing the five drilled sites on the western edge of the Galicia margin. Site 637 is the location of the hole from which the Galicia margin peridotite was recovered. Contour interval is $250 \mathrm{~m}$.

\section{Methods of Study}

Petrographic and analytical work on these samples was accomplished primarily on polished thin sections. Samples from the core were selected in an effort to minimize the amount of low-temperature alteration overprint (avoiding large serpentine and calcite veins, as well as clay alterations).

The recovered peridotite samples are from seven different cores of the drilled peridotite section. The top (Core 103-637A-23R) and bottom (Core 103-637A-29R) parts of the peridotite were the most altered. The central part of the peridotite (Cores 103-637A-25R through 103-638A27R) was the least altered. Much of the analytical work was done on the central section.

The thin sections were viewed under a petrographic microscope and then analyzed on the JEOL 733 electron microprobe at Rensselaer Polytechnic Institute. The instrument is equipped with 5 fully automated wavelength-dispersive spectrometers, three-axis stage automation $(x, y$, $z$ ), an energy dispersive detector, and backscatter, secondary, and X-ray imaging capabilities with image analysis hardware and software. All of the analytical and imaging capabilities of the machine were used to determine compositions and zoning in minerals, as well as textural relationships.

\section{Inferred Igneous Petrology of the Galicia Margin Peridotites}

Analysis of the alteration textures requires an understanding of the igneous mineralogy in the peridotites. Detailed descriptions of the igneous petrology, including criteria for distinguishing primary and secondary phases, can be found in Evans and Girardeau (this volume). A brief description of the mineralogy, as detailed in that paper, follows.

\section{Clinopyroxene}

Clinopyroxene grains are diopsidic with appreciable amounts of $\mathrm{Al}_{2} \mathrm{O}_{3}$ (3.0 to 7.0 weight percent [wt \%]). $\mathrm{Fe} /(\mathrm{Fe}+\mathrm{Mg}$ ) ranges from 0.07 to $0.08, \mathrm{TiO}_{2}$ from 0.1 to $0.9 \mathrm{wt} \%, \mathrm{Na}_{2} \mathrm{O}$ from 0.45 to $1.40 \mathrm{wt} \%$, and $\mathrm{Cr}_{2} \mathrm{O}_{3}$ from 0.5 to $1.5 \mathrm{wt} \%$.

\section{Orthopyroxene}

Primary orthopyroxenes have compositions ranging from $\mathrm{En}_{89}$ to $\mathrm{En}_{92}$, with an average composition of $\mathrm{En}_{90} . \mathrm{Al}_{2} \mathrm{O}_{3}$ ranges from 3.5 to $5.1 \mathrm{wt} \%$.

\section{Olivine}

Primary olivine was observed in only a few thin sections, although abundant serpentine mesh textures suggest that it was the dominant primary igneous phase. Olivine compositions are very uniform, from $\mathrm{Fo}_{89.4}$ to $\mathrm{Fo}_{90.6}$. Fine-grained recrystallized olivine has slightly more $\mathrm{Fe}$-rich compositions $\left(\mathrm{Fo}_{89.4}\right.$ to $\left.\mathrm{Fo}_{89.6}\right)$.

\section{Spinel}

Light brown to red chromium spinel grains occur in many of the thin sections. Some of these spinel grains have been elongated and brittlely fractured. The compositions of the clear, visibly unaltered grains are aluminous $(\mathrm{Cr} /(\mathrm{Cr}+\mathrm{Al})=0.10$ to 0.22) compared to other abyssal peridotites (Dick and Bullen, 1984). Magnetite rims some grains. Others are visibly zoned, becoming darker toward the rims. These spinel grains are enriched in $\mathrm{Fe}$ and $\mathrm{Cr}$ relative to $\mathrm{Mg}$ and $\mathrm{Al}$ toward the rims (Table 1).

Magnetite occurs in the calcite alteration rims around both clinopyroxene and orthopyroxene, as well as in the centers of late-stage serpentine veins.

\section{Plagioclase}

Plagioclase, where present, has compositions ranging from $\mathrm{An}_{75}$ to $\mathrm{An}_{80}$. Some plagioclase associated with chromium spinel has recrystallized to more sodium-rich compositions $\left(\mathrm{An}_{45}\right.$ to $\left.\mathrm{An}_{60}\right)$. Compositions of the primary igneous phases are given in Evans and Girardeau (this volume).

\section{ALTERATION TEXTURES}

\section{Clinopyroxene Hydration}

Apparent primary clinopyroxene grains either rimmed by tremolite \pm hornblende or containing tremolite in cracks are fairly common. In some places hornblende + tremolite or tremolite + chlorite are complete pseudomorphs of the clinopyroxene. Tremolite is used here to indicate a low-aluminum $\left(\mathrm{Al}_{2} \mathrm{O}_{3}\right.$ less than $4 \mathrm{wt} \%$ ), low-sodium ( $\mathrm{NaO}$ less than $1 \mathrm{wt} \%$ ), and highmagnesium $(\mathrm{Fe} / \mathrm{Fe}+\mathrm{Mg}$ less than 0.15$)$ calcic amphibole. Hornblende is used to describe any calcic amphibole containing more aluminum and/or more sodium than the preceding description of tremolite. These definitions are not in strict accordance with any published amphibole classifications but are used for the sake of clarity in the text.

Most clinopyroxene grains that do not have amphibole alteration rims have calcite alteration rims instead. Some calcite alteration rims are very thick $(0.2$ to $0.5 \mathrm{~mm})$ and occasionally completely replace the original pyroxene. 
Table 1. Representative analyses of spinel. Recalculated to 4 oxygens.

\begin{tabular}{|c|c|c|c|c|c|c|c|}
\hline & \multicolumn{7}{|c|}{ Samples from Core 103-637A-27R (section, interval) } \\
\hline & $\begin{array}{c}3 \\
(31-33 \mathrm{~cm})\end{array}$ & $\begin{array}{c}3 \\
(31-33 \mathrm{~cm})\end{array}$ & $\begin{array}{c}3 \\
(31-33 \mathrm{~cm})\end{array}$ & $\begin{array}{c}1 \\
(128 \mathrm{~cm})\end{array}$ & $\begin{array}{c}1 \\
(128 \mathrm{~cm})\end{array}$ & $\begin{array}{c}5 \\
(54-58 \mathrm{~cm})\end{array}$ & $\begin{array}{c}1 \\
(139 \mathrm{~cm})\end{array}$ \\
\hline $\mathrm{SiO}_{2}$ & 0.00 & 0.00 & 0.00 & 0.04 & 0.00 & 0.00 & 0.74 \\
\hline $\mathrm{Al}_{2} \mathrm{O}_{3}$ & 56.26 & 47.82 & 57.72 & 37.54 & 38.81 & 48.49 & 33.99 \\
\hline $\mathrm{TiO}_{2}$ & 0.15 & 0.20 & 0.05 & 0.37 & 0.37 & 0.05 & 0.09 \\
\hline $\mathrm{Cr}_{2} \mathrm{O}_{3}$ & 11.78 & 20.17 & 9.41 & 30.13 & 29.10 & 19.98 & 29.89 \\
\hline $\mathrm{MgO}$ & 19.86 & 18.07 & 20.83 & 15.70 & 15.32 & 17.71 & 11.10 \\
\hline${ }^{\mathrm{a}} \mathrm{FeO}$ & 11.37 & 13.92 & 11.49 & 16.05 & 15.76 & 13.28 & 23.19 \\
\hline $\mathrm{MnO}$ & 0.18 & 0.22 & 0.09 & 0.08 & 0.17 & 0.26 & 0.48 \\
\hline Total & 99.60 & 100.40 & 99.59 & 99.91 & $\overline{99.53}$ & 99.77 & 99.48 \\
\hline $\mathrm{Si}$ & 0.000 & 0.000 & 0.000 & 0.001 & 0.000 & 0.000 & 0.022 \\
\hline $\mathrm{Al}$ & 1.730 & 1.520 & 1.756 & 1.260 & 1.305 & 1.549 & 1.192 \\
\hline $\mathrm{Ti}$ & 0.003 & 0.004 & 0.001 & 0.008 & 0.008 & 0.001 & 0.002 \\
\hline $\mathrm{Fe}^{3+}$ & 0.021 & 0.042 & 0.050 & 0.047 & 0.023 & 0.020 & 0.057 \\
\hline $\mathrm{Cr}$ & 0.243 & 0.430 & 0.192 & 0.678 & 0.656 & 0.428 & 0.703 \\
\hline $\mathrm{Mg}$ & 0.772 & 0.726 & 0.801 & 0.666 & 0.651 & 0.715 & 0.492 \\
\hline $\mathrm{Fe}^{2+}$ & 0.227 & 0.272 & 0.198 & 0.335 & 0.353 & 0.281 & 0.520 \\
\hline $\mathrm{Mn}$ & 0.004 & 0.005 & 0.002 & 0.002 & 0.004 & 0.006 & 0.012 \\
\hline $\mathrm{Fe}^{2+} /\left(\mathrm{Fe}^{2+}+\mathrm{Mg}\right)$ & 0.227 & 0.273 & 0.198 & 0.335 & 0.352 & 0.282 & 0.514 \\
\hline $\mathrm{Cr} /(\mathrm{Cr}+\mathrm{Al})$ & 0.123 & 0.221 & 0.099 & 0.350 & 0.335 & 0.216 & 0.371 \\
\hline
\end{tabular}

Note: Analyses made on the JEOL Superprobe (RPI). Standards include synthetic pyroxene, synthetic fayalite, synthetic orthoclase, Amelia albite, chromite, ilmenite, and tephroite.

a Total Fe measured as $\mathrm{FeO}$. $\mathrm{Fe}_{2} \mathrm{O}_{3}$ recalculated based on stoichiometry.

\section{Orthopyroxene Hydration}

Orthopyroxene grains are typically elongate with tension fractures perpendicular to the long axis. These tension cracks commonly are filled with serpentine, rarely with calcite.

Much of the orthopyroxene is rimmed by serpentine. Orthopyroxene also is rimmed by calcite $(0.2$ to $0.5 \mathrm{~mm})$, and complete replacement of pyroxene by calcite is present. In these cases it is difficult to distinguish calcite pseudomorphs of orthopyroxene vs. clinopyroxene.

\section{Olivine Hydration}

Much of the primary olivine in the Galicia margin peridotite has been completely replaced by serpentine. The resultant serpentine mesh texture is common in many serpentinized peridotites (e.g., Aumento and Loubat, 1976). In some samples, serpentine cores of slightly more Fe-rich composition are found within the mesh texture. The serpentine mesh textures are cut by serpentine veins. These mesh textures consist predominantly of chrysotile, although some lizardite is present (Evans and Baltuck, this volume).

Calcite rims occur around large olivine grains. Calcite also occurs within the serpentine mesh texture. This calcite is similar in size and location to the olivine or serpentine cores found in other samples.

\section{Spinel Alteration}

Many spinel grains in the peridotite appear to be unaltered. Others are visibly zoned, becoming enriched in $\mathrm{Fe}$ and $\mathrm{Cr}$ relative to $\mathrm{Mg}$ and $\mathrm{Al}$ toward the rims. These zoned spinels are associated with hornblende or chlorite veins. In many cases spinel is unidirectionally zoned, rich in $\mathrm{Fe}$ and $\mathrm{Cr}$ relative to $\mathrm{Mg}$ and $\mathrm{Al}$ at the rims touching amphibole or chlorite, whereas it is unaltered (relative to the suggested "primary" compositions) near serpentine and calcite.

Some spinel grains are rimmed with magnetite. The small size of these grains and their magnetite rims precludes accurate analyses; hence, the extent of zoning is unknown.

\section{Alteration Veins}

\section{Amphibole Veins}

Veins of tremolite, tremolite + hornblende, and tremolite + chlorite can be found in the cores in the central section of the recovered peridotite. These veins vary in both width ( 0.05 to 2.0 $\mathrm{mm}$ ) and length $(0.5$ to $50 \mathrm{~mm})$. Some veins are mineralogically zoned and have either tremolite + hornblende edges and tremolite + chlorite centers or tremolite edges and tremolite + hornblende centers. In these veins tremolite is typically rimmed by hornblende. Representative analyses of amphibole are listed in Table 2.

\section{Serpentine Veins}

Serpentine veins are ubiquitous in these Galicia margin peridotites. The top and bottom parts of the recovered peridotite section (Cores 103-637A-23R and 103-637A-29R, respectively) contain $10 \%$ to $15 \%$ serpentine veins. The veins range from 0.05 to $2.0 \mathrm{~mm}$ in width and from 1.0 to $200 \mathrm{~mm}$ in length.

Several generations of veins are apparent from the cross-cutting relationships. Early-stage veins appear to run parallel to the foliation direction of the pyroxenes. Late-stage veins appear to cut this foliation at a high angle. In the center part of the peridotite section (Cores 103-637A-25R through 103-637A-27R), serpentine veins are not as abundant or as large $(0 \%$ to $5 \%$ veins; 0.05 to $1 \mathrm{~mm}$ wide and 0.1 to $5 \mathrm{~mm}$ long), but several generations of veins are present. Serpentine veins tend to cut the serpentine mesh textures (but not the calcite cores in the mesh textures), which suggests that the mesh textures formed prior to most of the serpentine veining. Representative analyses of serpentine are listed in Table 3.

\section{Calcite Veins}

Calcite veins also are abundant in the peridotites. The upper (Cores 103-637A-23R and 103-637A-24R) and lower (Cores 103637A-28R and 103-637A-29R) parts of the recovered peridotite section contain $5 \%$ to $25 \%$ calcite veins that range in size from 0.05 to $5 \mathrm{~mm}$ wide and 0.5 to $200 \mathrm{~mm}$ long (calcite veins and matrix-replacing calcite can locally comprise $100 \%$ of several 
Table 2. Representative analyses of amphibole, analyzed as in Table 1.

\begin{tabular}{|c|c|c|c|c|c|c|c|c|c|c|c|c|c|c|c|c|}
\hline \multirow[b]{3}{*}{ Mineral } & \multicolumn{16}{|c|}{ Samples from Hole 637A (core, section, interval) } \\
\hline & $\begin{array}{c}27 \mathrm{R}-2 \\
(126 \mathrm{~cm})\end{array}$ & $\begin{array}{c}27 \mathrm{R}-3 \\
(26-28 \mathrm{~cm})\end{array}$ & $\begin{array}{c}27 \mathrm{R}-1 \\
(128 \mathrm{~cm})\end{array}$ & $\begin{array}{c}27 \mathrm{R}-1 \\
(128 \mathrm{~cm})\end{array}$ & $\begin{array}{c}27 \mathrm{R}-1 \\
(128 \mathrm{~cm})\end{array}$ & $\begin{array}{c}27 \mathrm{R}-1 \\
(128 \mathrm{~cm})\end{array}$ & $\begin{array}{c}27 \mathrm{R}-1 \\
(128 \mathrm{~cm})\end{array}$ & $\begin{array}{c}27 \mathrm{R}-1 \\
(128 \mathrm{~cm})\end{array}$ & $\begin{array}{c}27 \mathrm{R}-3 \\
(31-33 \mathrm{~cm})\end{array}$ & $\begin{array}{c}27 \mathrm{R}-3 \\
(31-33 \mathrm{~cm})\end{array}$ & $\begin{array}{c}27 \mathrm{R}-3 \\
(31-33 \mathrm{~cm})\end{array}$ & $\begin{array}{c}27 \mathrm{R}-1 \\
(139 \mathrm{~cm})\end{array}$ & $\begin{array}{c}27 \mathrm{R}-1 \\
(139 \mathrm{~cm})\end{array}$ & $\begin{array}{c}27 \mathrm{R}-1 \\
(139 \mathrm{~cm})\end{array}$ & $\begin{array}{c}27 R-5 \\
(54-58 \mathrm{~cm})\end{array}$ & $\begin{array}{c}27 \mathrm{R}-5 \\
(54-58 \mathrm{~cm})\end{array}$ \\
\hline & Tremolite & Tremolite & Tremolite & Tremolite & HBD & Tremolite & HBD & Tremolite & Tremolite & Tremolite & Tremolite & Tremolite & Tremolite & HBD & Tremolite & HBD \\
\hline $\mathrm{SiO}_{2}$ & 57.38 & 57.09 & 55.86 & 55.53 & 43.99 & 57.84 & 41.88 & 57.70 & 54.21 & 56.87 & 58.03 & 55.41 & 57.37 & 41.93 & 42.88 & 56.63 \\
\hline $\mathrm{Al}_{2} \mathrm{O}_{3}$ & 1.01 & 0.55 & 1.28 & 1.20 & 13.36 & 0.31 & 13.53 & 0.49 & 3.50 & 1.05 & 0.13 & 1.75 & 0.75 & 14.48 & 14.17 & 1.33 \\
\hline $\mathrm{TiO}_{2}$ & 0.02 & 0.00 & 0.45 & 0.22 & 2.72 & 0.11 & 2.98 & 0.08 & 0.36 & 0.02 & 0.01 & 0.08 & 0.05 & 0.89 & 2.06 & 0.10 \\
\hline $\mathrm{Cr}_{2} \mathrm{O}_{3}$ & 0.02 & 0.00 & 0.00 & 0.34 & 1.28 & 0.00 & 1.89 & 0.14 & 0.36 & 0.00 & 0.01 & 0.22 & 0.00 & 1.37 & 2.49 & 0.58 \\
\hline $\mathrm{MgO}$ & 22.92 & 23.25 & 22.71 & 22.80 & 17.66 & 23.23 & 17.17 & 23.13 & 22.49 & 23.33 & 23.03 & 23.46 & 24.13 & 17.93 & 16.81 & 22.46 \\
\hline${ }^{\mathrm{a}} \mathrm{FeO}$ & 1.42 & 2.26 & 3.74 & 2.86 & 3.46 & 3.57 & 3.38 & 2.26 & 3.22 & 2.42 & 2.47 & 1.58 & 1.92 & 3.16 & 2.69 & 2.35 \\
\hline $\mathrm{MnO}$ & 0.07 & 0.00 & 0.00 & 0.05 & 0.06 & 0.15 & 0.00 & 0.00 & 0.09 & 0.16 & 0.13 & 0.12 & 0.16 & 0.13 & 0.14 & 0.18 \\
\hline $\mathrm{CaO}$ & 13.38 & 13.05 & 13.19 & 12.53 & 12.92 & 12.07 & 13.01 & 13.66 & 12.21 & 12.24 & 13.25 & 13.78 & 13.32 & 12.27 & 11.74 & 11.87 \\
\hline $\mathrm{Na}_{2} \mathrm{O}$ & 0.24 & 0.22 & 0.51 & 0.49 & 3.27 & 0.16 & 3.49 & 0.23 & 0.91 & 0.47 & 0.10 & 0.49 & 0.11 & 3.17 & 3.47 & 0.45 \\
\hline $\mathrm{K}_{2} \mathrm{O}$ & 0.00 & 0.00 & 0.01 & 0.00 & 0.00 & 0.00 & 0.00 & 0.02 & 0.03 & 0.02 & 0.02 & 0.00 & 0.00 & 0.24 & 0.28 & 0.05 \\
\hline Total & 96.44 & 96.42 & 97.75 & 96.02 & 98.72 & 97.44 & 97.33 & 97.71 & 97.41 & 96.58 & 97.18 & 96.89 & 97.81 & 95.57 & 96.73 & 96.00 \\
\hline${ }^{\mathrm{b}} \mathrm{Si}$ & 7.923 & 7.915 & 7.712 & 7.802 & 6.188 & 7.956 & 6.015 & 7.909 & 7.511 & 7.873 & 7.987 & 7.774 & 7.895 & 6.064 & 6.148 & 7.878 \\
\hline $\mathrm{Al}^{\mathrm{iv}}$ & 0.077 & 0.085 & 0.209 & 0.198 & 1.812 & 0.044 & 1.985 & 0.083 & 0.489 & 0.127 & 0.013 & 0.226 & 0.105 & 1.936 & 1.852 & 0.122 \\
\hline $\mathrm{Al}^{\mathrm{vi}}$ & 0.087 & 0.005 & 0.000 & 0.001 & 0.404 & 0.006 & 0.306 & 0.000 & 0.082 & 0.044 & 0.008 & 0.064 & 0.016 & 0.533 & 0.544 & 0.096 \\
\hline $\mathrm{Ti}$ & 0.002 & 0.000 & 0.047 & 0.023 & 0.288 & 0.011 & 0.322 & 0.008 & 0.037 & 0.002 & 0.001 & 0.008 & 0.005 & 0.097 & 0.222 & 0.010 \\
\hline $\mathrm{Fe}^{3+}$ & 0.000 & 0.000 & 0.000 & 0.000 & 0.000 & 0.000 & 0.000 & 0.000 & 0.043 & 0.000 & 0.000 & 0.000 & 0.000 & 0.224 & 0.000 & 0.033 \\
\hline $\mathrm{Cr}$ & 0.002 & 0.000 & 0.000 & 0.038 & 0.142 & 0.000 & 0.215 & 0.015 & 0.039 & 0.000 & 0.001 & 0.024 & 0.000 & 0.157 & 0.282 & 0.064 \\
\hline $\mathrm{Mg}$ & 4.716 & 4.805 & 4.673 & $\begin{array}{l}4.775 \\
\end{array}$ & 3.703 & 4.762 & 3.675 & 4.725 & $\begin{array}{l}.0644 \\
\end{array}$ & 4.814 & 4.723 & $\begin{array}{l}4.906 \\
\end{array}$ & $\begin{array}{l}4.950 \\
\end{array}$ & 3.864 & 3.593 & 4.656 \\
\hline $\mathrm{Fe}^{2+}$ & 0.164 & 0.262 & 0.432 & 0.336 & 0.407 & 0.411 & 0.406 & 0.259 & 0.330 & 0.280 & 0.284 & 0.185 & 0.221 & 0.158 & 0.322 & 0.240 \\
\hline $\mathrm{Mn}$ & 0.008 & 0.000 & 0.000 & 0.006 & 0.007 & 0.017 & 0.000 & 0.000 & 0.011 & 0.019 & 0.015 & 0.014 & 0.019 & 0.016 & 0.017 & 0.021 \\
\hline Sum Oct & 4.979 & 5.072 & 5.152 & 5.179 & 4.951 & 5.207 & 4.924 & 5.007 & 5.186 & 5.159 & 5.032 & 5.201 & 5.211 & 5.049 & 4.980 & 5.120 \\
\hline $\mathrm{Ca}$ & 1.980 & 1.939 & 1.951 & 1.887 & 1.948 & 1.779 & 2.002 & 2.006 & 1.813 & 1.816 & 1.954 & 2.071 & 1.965 & 1.901 & 1.803 & 1.770 \\
\hline $\mathrm{Na}(\mathrm{M} 4)$ & 0.020 & 0.000 & 0.000 & 0.000 & 0.101 & 0.014 & 0.000 & 0.000 & 0.001 & 0.025 & 0.014 & 0.000 & 0.000 & 0.050 & 0.217 & 0.110 \\
\hline $\mathrm{Na}(\mathrm{A})$ & 0.044 & 0.059 & 0.137 & 0.133 & 0.791 & 0.029 & 0.972 & 0.061 & 0.243 & 0.101 & 0.013 & 0.132 & 0.029 & 0.839 & 0.747 & 0.011 \\
\hline $\mathrm{K}$ & 0.000 & 0.000 & 0.002 & 0.000 & 0.000 & 0.000 & 0.000 & 0.003 & 0.005 & 0.004 & 0.004 & 0.000 & 0.000 & 0.044 & 0.051 & 0.009 \\
\hline Sum $A$ & 0.044 & 0.059 & 0.139 & 0.133 & 0.791 & 0.029 & 0.972 & 0.064 & 0.248 & 0.105 & 0.017 & 0.132 & 0.029 & 0.883 & 0.798 & 0.020 \\
\hline $\mathrm{Fe}^{2+} /\left(\mathrm{Fe}^{2+}+\mathrm{Mg}\right)$ & 0.034 & 0.052 & 0.085 & 0.066 & 0.099 & 0.079 & 0.099 & 0.052 & 0.066 & 0.055 & 0.057 & 0.036 & 0.043 & 0.039 & 0.082 & 0.049 \\
\hline $\mathrm{Fe}^{3+} /\left\langle\mathrm{Fe}^{\mathrm{T}}\right\rangle$ & 0.000 & 0.000 & 0.000 & 0.000 & 0.000 & 0.000 & 0.000 & 0.000 & 0.115 & 0.000 & 0.000 & 0.000 & 0.000 & 0.586 & 0.000 & 0.121 \\
\hline
\end{tabular}

Total Fe as $\mathrm{FeO}$.

Note: HBD $=$ hornblende. 
Table 3. Representative analyses of serpentine (SERP) and chlorite (CHL), calculated as in Table 1.

\begin{tabular}{|c|c|c|c|c|c|c|c|c|c|c|}
\hline & \multicolumn{10}{|c|}{ Samples from 103-637A-27R (interval) } \\
\hline & $\begin{array}{c}(26-28 \mathrm{~cm}) \\
\mathrm{CHL}\end{array}$ & $\begin{array}{c}(26-28 \mathrm{~cm}) \\
\mathrm{CHL}\end{array}$ & $\begin{array}{c}(128 \mathrm{~cm}) \\
\mathrm{CHL}\end{array}$ & $\begin{array}{l}(126 \mathrm{~cm}) \\
\text { SERP }\end{array}$ & $\begin{array}{l}(128 \mathrm{~cm}) \\
\text { SERP }\end{array}$ & $\begin{array}{c}(31-33 \mathrm{~cm}) \\
\text { SERP }\end{array}$ & $\begin{array}{c}(26-28 \mathrm{~cm}) \\
\text { SERP }\end{array}$ & $\begin{array}{l}(139 \mathrm{~cm}) \\
\text { SERP }\end{array}$ & $\begin{array}{l}(139 \mathrm{~cm}) \\
\text { SERP }\end{array}$ & $\begin{array}{c}(54-58 \mathrm{~cm}) \\
\text { SERP }\end{array}$ \\
\hline $\mathrm{SiO}_{2}$ & 36.18 & 37.68 & 34.24 & 40.82 & 40.76 & 41.12 & 41.74 & 40.32 & 41.43 & 38.73 \\
\hline $\mathrm{Al}_{2} \mathrm{O}_{3}$ & 12.82 & 11.20 & 12.42 & 2.57 & 0.81 & 0.28 & 1.01 & 0.03 & 0.00 & 1.47 \\
\hline $\mathrm{TiO}_{2}$ & 0.00 & 0.02 & 0.06 & 0.08 & 0.11 & 0.00 & 0.00 & 0.03 & 0.00 & 0.05 \\
\hline $\mathrm{Cr}_{2} \mathrm{O}_{3}$ & 0.03 & 0.00 & 0.62 & 0.73 & 0.03 & 0.00 & 0.00 & 0.00 & 0.00 & 0.49 \\
\hline $\mathrm{MgO}$ & 33.12 & 31.72 & 33.45 & 32.83 & 34.88 & 39.88 & 34.70 & 38.46 & 38.49 & 37.57 \\
\hline${ }^{\mathrm{a}} \mathrm{FeO}$ & 4.65 & 5.84 & 4.40 & 8.58 & 8.52 & 4.13 & 7.83 & 6.10 & 5.27 & 5.62 \\
\hline $\mathrm{MnO}$ & 0.05 & 0.09 & 0.00 & 0.07 & 0.14 & 0.02 & 0.10 & 0.12 & 0.12 & 0.10 \\
\hline Total & 86.85 & 86.55 & 85.19 & 85.68 & 85.25 & 85.43 & 85.38 & 85.06 & 85.31 & 84.03 \\
\hline${ }^{b} \mathrm{Si}$ & 6.827 & 7.156 & 6.614 & 1.991 & 2.002 & 1.976 & 2.034 & 1.968 & 2.003 & 1.905 \\
\hline $\mathrm{Al}$ & 2.851 & 2.508 & 2.828 & 0.148 & 0.047 & 0.016 & 0.058 & 0.002 & 0.000 & 0.085 \\
\hline $\mathrm{Ti}$ & 0.000 & 0.003 & 0.009 & 0.003 & 0.004 & 0.000 & 0.000 & 0.001 & 0.000 & 0.002 \\
\hline $\mathrm{Cr}$ & 0.005 & 0.000 & 0.095 & 0.028 & 0.001 & 0.000 & 0.000 & 0.000 & 0.000 & 0.019 \\
\hline $\mathrm{Mg}$ & 9.313 & 8.977 & 9.630 & 2.386 & 2.553 & 2.856 & 2.520 & 2.798 & 2.773 & 2.754 \\
\hline $\mathrm{Fe}^{2+}$ & 0.734 & 0.928 & 0.711 & 0.350 & 0.350 & 0.166 & 0.319 & 0.249 & 0.213 & 0.231 \\
\hline $\mathrm{Mn}$ & 0.008 & 0.014 & 0.000 & 0.003 & 0.006 & 0.001 & 0.004 & 0.005 & 0.005 & 0.004 \\
\hline $\mathrm{Fe} /(\mathrm{Fe}+\mathrm{Mg})$ & 0.073 & 0.094 & 0.069 & 0.128 & 0.121 & 0.055 & 0.112 & 0.082 & 0.071 & 0.077 \\
\hline
\end{tabular}

a Total $\mathrm{Fe}$ as $\mathrm{FeO}$.

b Chlorite recalculated to 22 oxygens, serpentine to 9 .

centimeters of rock). Calcite veins may be vugged, containing calcite crystals several millimeters long.

In the middle part of the peridotite section (Cores 103-637A$25 \mathrm{R}$ through 103-637A-27R), calcite veins are restricted in their spatial extent to approximately every $10 \mathrm{~cm}$. The rock between these large calcite veins is the least altered part of the core.

\section{ALTERATION REACTIONS}

\section{Clinopyroxene Hydration}

\section{Hydration of Clinopyroxene to Amphibole}

Clinopyroxene with amphibole rims, a common texture in hydrothermally altered abyssal ultramafic rocks, has been interpreted in samples from other localities to be the result of relatively high-temperature hydration of the clinopyroxene (Kimball et al., 1985). In the Galicia margin peridotites, clinopyroxene commonly is rimmed by tremolite. One possible reaction, conserving $\mathrm{MgO}$, is

$$
5 \mathrm{CaMgSi}_{2} \mathrm{O}_{6}+\mathrm{H}_{2} \mathrm{O}=\mathrm{Ca}_{2} \mathrm{Mg}_{5} \mathrm{Si}_{8} \mathrm{O}_{22}(\mathrm{OH})_{2}+3 \mathrm{CaO}+2 \mathrm{SiO}_{2} \text {, }
$$

where CPX $=$ clinopyroxene and TREM = tremolite. This $\mathrm{MgO}$-conserving reaction is suggested because previous work indicates that the hydrothermal fluids responsible for the hydration of pyroxene to amphibole in other ultramafic rocks are relatively rich in $\mathrm{Ca}$ and $\mathrm{Si}$ relative to $\mathrm{Mg}$ (e.g., Kimball and Spear, 1984).

An alternative method of looking at the reaction involves analysis of the extent of reaction progress (e.g., Ferry, 1983; Kimball et al., 1985). For the hydration of pure diopside to tremolite in terms of $\mathrm{CaO}, \mathrm{MgO}, \mathrm{SiO}_{2}$, and $\mathrm{H}_{2} \mathrm{O}$, there are two phases and four components. Two linearly independent equations can be written, for example:

$$
\begin{aligned}
1000 \mathrm{~cm}^{3} \text { (15.1 moles) } \mathrm{CPX}= & 15.1 \mathrm{CaO}+15.1 \mathrm{MgO} \\
& +30.2 \mathrm{SiO}_{2} \\
1000 \mathrm{~cm}^{3} \text { (3.7 moles) TREM }= & 7.3 \mathrm{CaO}+18.3 \mathrm{MgO} \\
& +29.3 \mathrm{SiO}_{2}+3.7 \mathrm{H}_{2} \mathrm{O} .
\end{aligned}
$$

These equations are balanced in terms of volumes $\left(\mathrm{cm}^{3}\right)$ of minerals (using data from Helgeson et al., 1978) and moles of $\mathrm{CaO}$, $\mathrm{MgO}, \mathrm{SiO}_{2}$, and $\mathrm{H}_{2} \mathrm{O}$ to help correlate the volume of rock to changes in the composition of the fluid altering the rock. These equations can be represented graphically. In Figure $2 \mathrm{~A}$ the volume of clinopyroxene consumed is plotted on the vertical axis, and volume of tremolite produced is plotted on the horizontal axis. The diagram (Fig. 2A) is contoured in moles of $\mathrm{CaO}$, $\mathrm{MgO}, \mathrm{SiO}_{2}$, and $\mathrm{H}_{2} \mathrm{O}$ added to (positive contours) or subtracted from (negative contours) the fluid. Note that the $\mathrm{H}_{2} \mathrm{O}$ contours are always negative; $\mathrm{H}_{2} \mathrm{O}$ is, of course, required to hydrate clinopyroxene to tremolite.

To evaluate the chemical changes occurring during hydration in the absence of an inert marker in the rock, it is necessary to make an assumption about the volume change of the rock during hydration. One such assumption is that of constant volume. The constant-volume reaction, derived by subtracting equation (3) from equation (2), can be written as

$$
\begin{aligned}
1000 \mathrm{~cm}^{3} \mathrm{CPX}+3.7 \mathrm{H}_{2} \mathrm{O}+3.2 \mathrm{MgO}= & 1000 \mathrm{~cm}^{3} \mathrm{TREM} \\
& +7.8 \mathrm{CaO}+0.9 \mathrm{SiO}_{2}
\end{aligned}
$$

and is shown in Figure $2 \mathrm{~A}$ as a heavy, diagonal line. The amounts of $\mathrm{CaO}, \mathrm{MgO}, \mathrm{SiO}_{2}$, and $\mathrm{H}_{2} \mathrm{O}$ added to or subtracted from the fluid depend, of course, on the reaction progress. If no $\left(0 \mathrm{~cm}^{3}\right)$ clinopyroxene is consumed, then no $\mathrm{MgO}$ or $\mathrm{H}_{2} \mathrm{O}$ is used, and no $\mathrm{CaO}$ and $\mathrm{SiO}_{2}$ are produced. At $500-\mathrm{cm}^{3}$ clinopyroxene consumed, $1.8 \mathrm{H}_{2} \mathrm{O}$ and $1.6 \mathrm{MgO}$ have been subtracted from the fluid and $3.9 \mathrm{CaO}$ and $0.45 \mathrm{SiO}_{2}$ added to the fluid (see Fig. 2A).

The slope of the contour lines relative to the constant-volume reaction line gives an estimate of how sensitive the molar quantities are to the assumption of the constant-volume. For example, the slopes of $\mathrm{CaO}$ contours are shallow relative to the slope of the constant-volume reaction line. Therefore, $\mathrm{CaO}$ will be released to the fluid unless there is a very large volume increase $(200 \%)$ during hydration. The $\mathrm{SiO}_{2}$ and $\mathrm{MgO}$ contours have slopes similar to that of the constant-volume hydration line. Therefore, for constant-volume hydration, $\mathrm{SiO}_{2}$ is released in small quantities, but with a $3 \%$ volume increase during hydration $\mathrm{SiO}_{2}$ is conserved. Further volume increases during hydration would result in the reaction requiring $\mathrm{SiO}_{2}$ from the fluid (Fig. 2A). $\mathrm{MgO}$ is also consumed during the reaction. An 
A

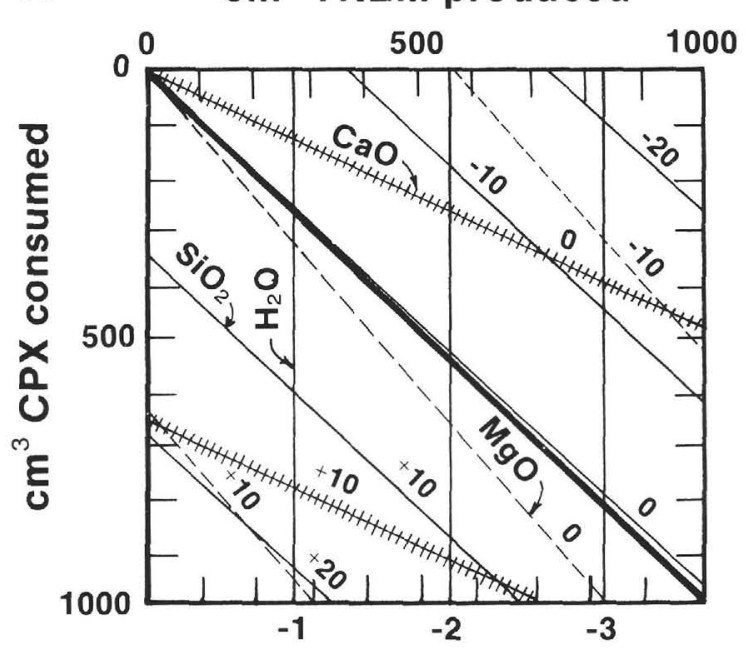

C

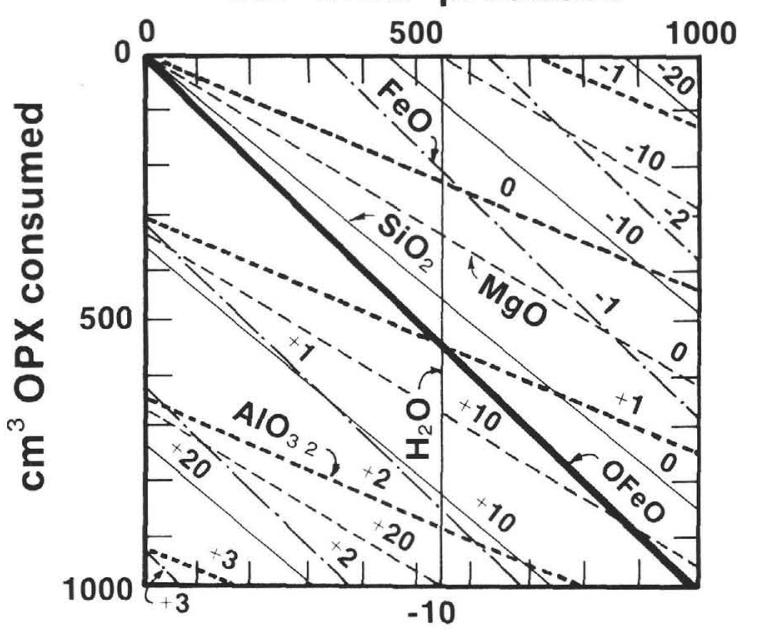

B

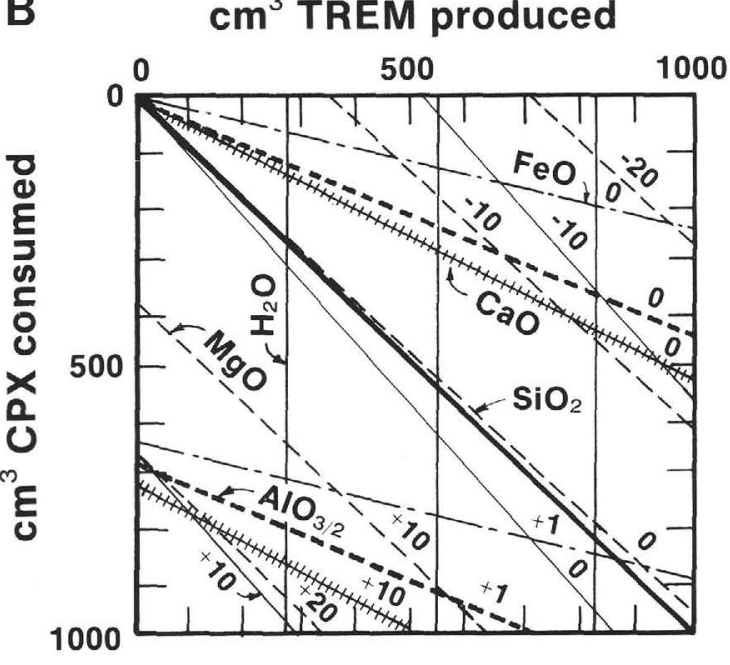

D

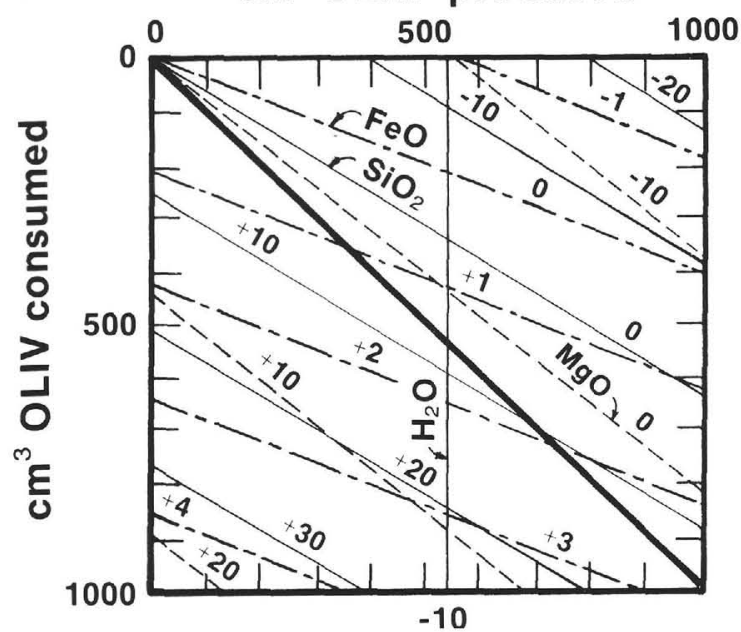

Figure 2. Graphical representations of the reaction spaces. Volumes of the original mineral are plotted on the y-axis, volumes of the hydration mineral are plotted on the x-axis. Contours are plotted for molar quantities of $\mathrm{MgO}$ (dotted), $\mathrm{FeO}$ (dashed), $\mathrm{SiO}_{2}$ (light solid), $\mathrm{AlO}_{3 / 2}$ (heavy dashed), $\mathrm{CaO}$ (hatchured), and $\mathrm{H}_{2} \mathrm{O}$ (vertical, medium solid) released to $(+)$ and taken from $(-)$ the fluid. Zero contours are conservative. The constant-volume reaction line is the heavy diagonal line. A. Pure diopside $\left(\mathrm{MgCaSi}_{2} \mathrm{O}_{6}\right)(\mathrm{CPX})$ hydrating to tremolite $\left(\mathrm{Ca}_{2} \mathrm{Mg}_{5} \mathrm{Si}_{8} \mathrm{O}_{22}(\mathrm{OH})_{2}\right)$ (TREM) at constant volume. B. Galicia margin clinopyroxene $\left(\mathrm{Ca}_{0.9} \mathrm{Mg}_{1.0} \mathrm{Fe}_{0.1} \mathrm{Si}_{1.9} \mathrm{Al}_{0.1} \mathrm{O}_{6}\right)$ hydrating to tremolite $\left(\mathrm{Ca}_{2} \mathrm{Mg}_{4.9} \mathrm{Fe}_{0.1} \mathrm{Al}_{0.2} \mathrm{Si}_{7.8} \mathrm{O}_{22}(\mathrm{OH})_{2}\right)$ at constant volume. C. Orthopyroxene $\left(\mathrm{Mg}_{1.7} \mathrm{Fe}_{0.2} \mathrm{Al}_{0.2} \mathrm{Si}_{1.9} \mathrm{O}_{6}\right)(\mathrm{OPX})$ hydrating to serpentine $\left(\mathrm{Mg}_{2.5} \mathrm{Fe}_{0.4} \mathrm{Al}_{0.1} \mathrm{Si}_{2} \mathrm{O}_{5}(\mathrm{OH})_{4}\right)(\mathrm{SERP})$ at constant volume. D. Olivine $\left(\mathrm{Mg}_{1.8} \mathrm{Fe}_{0.2} \mathrm{SiO}_{4}\right)$ (OLIV) hydrating to serpentine $\left(\mathrm{Mg}_{2.8} \mathrm{Fe}_{0.2} \mathrm{Si}_{2} \mathrm{O}_{5}(\mathrm{OH})_{4}\right)$ at constant volume.

$18 \%$ volume decrease during hydration is required to conserve $\mathrm{MgO}$ (Fig. 2). Assuming no volume decrease during hydration, equation (4) represents the maximum amount of $\mathrm{CaO}$ and $\mathrm{SiO}_{2}$ released to the fluid and the minimum amount of $\mathrm{MgO}$ taken from the fluid during hydration.

Compositions of tremolite rims on diopside in the Galicia margin peridotite (Table 3 ) are plotted on Figure 2B. The actual mineral compositions include minor $\mathrm{FeO}$ and $\mathrm{AlO}_{3 / 2}$ as well as $\mathrm{MgO}, \mathrm{CaO}$, and $\mathrm{SiO}_{2}$. The constant-volume hydration reaction can be written

$$
\begin{aligned}
1000 \mathrm{~cm}^{3} \mathrm{CPX}+3.6 \mathrm{H}_{2} \mathrm{O}+2.8 \mathrm{MgO}= & 1000 \mathrm{~cm}^{3} \mathrm{TREM} \\
& +6.3 \mathrm{CaO}+1.1 \mathrm{FeO} \\
& +0.8 \mathrm{AlO}_{3 / 2} \\
& +0.7 \mathrm{SiO}_{2} .
\end{aligned}
$$

Both the $\mathrm{FeO}$ and $\mathrm{AlO}_{3 / 2}$ contours are shallow with respect to the constant-volume reaction line; small amounts of $\mathrm{FeO}$ and $\mathrm{AlO}_{3 / 2}$ are released to the fluid during hydration.

\section{Other Amphibole Reactions}

In addition to the tremolite rims on clinopyroxene, other alteration textures involving amphiboles are present in the Galicia margin peridotite. These include hornblende rims on clinopyroxene, hornblende rims on tremolite (some of the tremolite rims clinopyroxene), and chlorite + tremolite pseudomorphs of amphibole.

One way to interpret the multiple amphibole textures in these rocks is in terms of the calcic amphibole solvus (as in Kimball et al., 1985; Kimball, in press) and the pyroxene and amphibole breakdown reactions represented on it. Although there is much discussion in the literature about the presence (e.g., Robinson et al., 1981) or absence (e.g., Grapes and Graham, 1978) of a calcic amphibole solvus, experimental evidence suggests a well-defined solvus (e.g., Oba, 1980), and many hornblende-actinolite pairs have been observed in nature (e.g., Klein, 1969; Cooper and Lovering, 1970; Brady, 1974; Misch and Rice, 1975; Tagiri, 1977; Graham, 1974; Sampson and Fawcett, 1977). Although 
the shape and exact temperature of the crest of the solvus are not known, a stylized solvus has been constructed (using the cited data; after Robinson et al., 1981) and is shown as Figure 3. The pyroxene/amphibole boundary shown is the lower limit based on Spear's (1981) experimental data; the $600^{\circ} \mathrm{C}$ solvus crest is consistent with the metamorphic conditions cited in the literature (near $5 \mathrm{kbar}$ ). However, it should be noted that there is evidence that the solvus has a negative $\mathrm{dP} / \mathrm{dT}$ slope (Oba, 1980), and at lower pressures the crest of the solvus may be at higher temperatures.

Several amphibole, pyroxene, and chlorite compositions from the Galicia margin samples have been plotted on the solvus (Fig. 3). Tremolites with relatively high $\mathrm{Al}^{\text {iv }}$ contents (0.3-0.5) are considered supersolvus, and lower $\mathrm{Al}^{\mathrm{iv}}(0.0$ to 0.3$)$ tremolites coexisting with hornblende $\left(\mathrm{Al}^{\mathrm{iv}}=0.6\right.$ to 1.3$)$ or chlorite are considered subsolvus (Fig. 3). Sample 103-637A27R-1, 128-130 cm, (circles) contains supersolvus tremolite, subsolvus tremolite + hornblende, and subsolvus tremolite + chlorite. The supersolvus amphiboles contain more $\mathrm{Al}^{\text {iv }}$ than the primary clinopyroxene. Sample 103-637A-27R-1, 139-140 cm, (triangles) contains supersolvus and subsolvus amphiboles but no chlorite. These are representative of the mineralogies present in the altered clinopyroxenes. The mineral compositions are shown on Figure 3.

\section{Suggested Spinel Reaction}

Both samples plotted on Figure 3 had similar clinopyroxene compositions. Sample 103-637A-27R-1, 139-140 cm, (triangles) has amphibole and chlorite compositions that could be explained by isochemical (excluding $\mathrm{H}_{2} \mathrm{O}$ ) hydration of clinopyroxene to tremolite, followed by the exsolution of hornblende from tremolite at lower temperatures. The second plotted sample (103-637A-27R-1, 128-130 cm; circles) has amphibole compositions that do not seem to be obtainable by an isochemical hydration of the primary clinopyroxene. The configuration of the plot suggests that $\mathrm{Al}$ was added to the system. The suggested source of $\mathrm{Al}$ for these amphiboles is the now altered $\mathrm{Cr}$-spinel (as in Kimball, 1985, in press). Cr-spinel in these samples is enriched in $\mathrm{Fe}$ and $\mathrm{Cr}$ at its rims relative to its cores (Table 1). The mechanism proposed is that the $\mathrm{MgAl}_{2} \mathrm{O}_{4}$ component of the spinel is reacting with the diopside component in the clinopyroxene to produce amphibole. This reaction mechanism has been suggested for aluminous amphibole formation in the ultramafics of the Islas Orcadas Fracture Zone ultramafics (Kimball et al., 1985) and the Josephine ophiolite (Kimball, 1988).

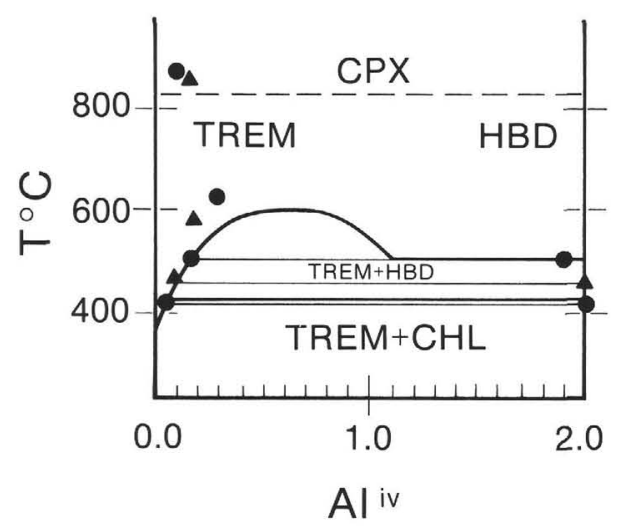

Figure 3. Schematic actinolite-hornblende solvus, after Robinson et al. (1981). For detailed discussion see text. CPX = primary clinopyroxene, TREM = tremolite, $\mathrm{HBD}=$ hornblende, $\mathrm{CHL}=$ chlorite. Samples plotted are 103-637A-27R-1, 128-130 cm (circles) and 103-637A-27R-1, $139-140 \mathrm{~cm}$ (triangles).

\section{Carbonate Reactions}

Clinopyroxene from the peridotites in the upper (Cores 103637A-23R and 103-637A-24R) and lower (Cores 103-637A-28R and 103-637A-29R) parts of the peridotite section often are rimmed by calcite. Trommsdorff and Evans (1977) suggest, in their work on calcite-bearing ultramafic samples in the Alps, that the stable alteration assemblage in ophicalcites is calcite + serpentine. The reaction they propose involves the phases olivine and clinopyroxene altering to serpentine and calcite. Trommsdorff and Evans (1977) represent that reaction by the equation

$$
62 \mathrm{OLIV}+20 \mathrm{CPX}+93 \mathrm{H}_{2} \mathrm{O}+20 \mathrm{CO}_{2}=20 \mathrm{CALC}
$$

where ANTI = antigorite $\left(\mathrm{Mg}_{48} \mathrm{Si}_{34} \mathrm{O}_{85}(\mathrm{OH})_{62}\right)$, OLIV = olivine, $\mathrm{CPX}=$ diopside, and $\mathrm{CALC}=$ calcite. This chemical reaction involves the addition of only water and $\mathrm{CO}_{2}$ to the rock.

Because the serpentine polymorphs in the Galicia margin samples are lizardite and chrysotile (Evans and Baltuck, this volume) the reaction in equation (6) could be rewritten as

$$
\begin{aligned}
& 4 \mathrm{Mg}_{2} \mathrm{SiO}_{4}+\mathrm{CaMgSi}_{2} \mathrm{O}_{6}+6 \mathrm{H}_{2} \mathrm{O}+\mathrm{CO}_{2}=\mathrm{CaCO}_{3} \\
& \text { OLIV } \mathrm{CPX}-\mathrm{CALC} \\
& +3 \mathrm{Mg}_{3} \mathrm{Si}_{2} \mathrm{O}_{5}(\mathrm{OH})_{4}
\end{aligned}
$$

where SERP = chrysotile or lizardite. This reaction also requires addition of $\mathrm{H}_{2} \mathrm{O}$ and $\mathrm{CO}_{2}$ to the rock.

Although the predominant alteration minerals now present in the peridotite are serpentine and calcite, there is no evidence that other phases were involved in the alteration of clinopyroxene to calcite. In fact, the isotopic work of Evans and Baltuck (this volume) suggests that calcite not only formed very late in the alteration sequence but formed from seawater at deep-sea temperatures after the emplacement of the ultramafic rock to the surface. Ignoring all other phases, the constant volume alteration of clinopyroxene to calcite can be represented as

$$
\begin{aligned}
1000 \mathrm{~cm}^{3} \mathrm{CPX}+12 \mathrm{CaO}+27 \mathrm{CO}_{2}= & 1000 \mathrm{~cm}^{3} \mathrm{CALC} \\
& +15 \mathrm{MgO}+30 \mathrm{SiO}_{2} .
\end{aligned}
$$

\section{Orthopyroxene Hydration}

Orthopyroxene generally is hydrated to serpentine. This reaction can be represented at constant volume by

$$
\begin{aligned}
1000 \mathrm{~cm}^{3} \mathrm{OPX}+18.4 \mathrm{H}_{2} \mathrm{O}+0.0 \mathrm{FeO}= & 1000 \mathrm{~cm}^{3} \mathrm{SERP} \\
& +4.1 \mathrm{MgO}+11.8 \mathrm{SiO}_{2} \\
& +1.8 \mathrm{AlO}_{3 / 2},
\end{aligned}
$$

where OPX $=$ orthopyroxene and SERP = serpentine (chrysotile or lizardite). This reaction is plotted on Figure $2 \mathrm{C}$.

\section{Olivine Hydration}

The serpentinization of olivine is a common reaction in the ultramafic cumulates. The constant-volume hydration of olivine to serpentine can be written as

$$
\begin{aligned}
1000 \mathrm{~cm}^{3} \text { OLIV }+18.4 \mathrm{H}_{2} \mathrm{O}= & 1000 \mathrm{~cm}^{3} \mathrm{SERP}+2.7 \mathrm{FeO} \\
& +4.3 \mathrm{SiO}_{2}+15.2 \mathrm{MgO}
\end{aligned}
$$

where OLIV = olivine and SERP = serpentine. The reaction space for the olivine hydration to serpentine is shown as Figure $2 \mathrm{D}$. Notice that the slope of the FeO contours relative to the constant-volume reaction line is very shallow. Relatively large 
quantities of $\mathrm{FeO}$ from the fluid are required for the constantvolume hydration of olivine to form the surrounding serpentine. More $\mathrm{SiO}_{2}$ and less $\mathrm{MgO}$ are released than during orthopyroxene hydration.

\section{ALTERATION TEMPERATURES}

The results of mineral stability experiments can be used to place constraints on the temperatures at which many of the hydration reactions occurred. Table 4 summarizes the pertinent reactions discussed above. These reactions are also plotted in Figure 4. The curves in Figure 4 are plotted assuming $\mathrm{P}\left(\mathrm{H}_{2} \mathrm{O}\right)=$ $\mathrm{P}$ (Total) and pure $\mathrm{Mg}$ systems (no Fe solid solutions). Lowering $\mathrm{X}_{\mathrm{Mg}}$ (increasing $\mathrm{Fe}$ components) lowers the reaction temperatures by several degrees. Lowering $\mathrm{P}\left(\mathrm{H}_{2} \mathrm{O}\right)$ to $0.5 \mathrm{P}$ (Total) results in lowering the reaction temperatures $60^{\circ}$ to $75^{\circ} \mathrm{C}$ (depending on total pressure). Both the temperature and pressure changes can be calculated using data in Helgeson et al. (1978) and Burnham et al. (1969). Consequently, the temperatures in Table 4 and Figure 4 are maximum reaction temperatures.

\section{Clinopyroxene Reactions}

\section{Clinopyroxene Hydration to Amphibole}

The most common clinopyroxene alteration reaction in the Galicia margin peridotite is the hydration of clinopyroxene to tremolite. The proposed reaction is represented by equation (1). As all of the published experimental work on amphibole/pyroxene phase relations has been done on closed systems, all of the experimental run products contain phases other than tremolite and clinopyroxene. Furthermore, most of these experiments were designed to determine the high-temperature breakdown of amphibole to pyroxene, not the low-temperature breakdown of pyroxene to amphibole. However, the results of these experiments, although not strictly applicable, can be used to constrain clinopyroxene hydration temperatures.

One of the earliest tremolite stability experiments was done by Boyd (1959). Pure tremolite breaks down to enstatite + diopside + quartz at $825^{\circ} \mathrm{C}$ and $1 \mathrm{kbar}\left(900^{\circ} \mathrm{C}\right.$ at $5 \mathrm{kbar}, 875^{\circ} \mathrm{C}$ at 2 kbar). However, Jasmund and Schafer (1972) show results suggesting that pure tremolite (no $\mathrm{Fe}$ ) reacts to diopside + enstatite + anorthite + quartz near $850^{\circ} \mathrm{C}$ at 2 kbar. Oba's (1980) work, suggesting that the pyroxene/amphibole curves actually have negative $\mathrm{dP} / \mathrm{dT}$ slopes, shows tremolite breaking down to clinopyroxene + orthopyroxene + quartz $+\mathrm{H}_{2} \mathrm{O}$ near $830^{\circ} \mathrm{C}$ at $1 \mathrm{kbar}$, and near $700^{\circ} \mathrm{C}$ at $5 \mathrm{kbar}$.

The addition of the iron end-member results in a lower temperature breakdown of the amphibole, as shown in Cameron's (1975) work, suggesting that tremolite with $\mathrm{Mg} /(\mathrm{Mg}+\mathrm{Fe})=$ 0.5 will break down to tremolite + clinopyroxene + quartz near $575^{\circ} \mathrm{C}$ at $2 \mathrm{kbar}$. The first appearance of tremolite in the hydration of clinopyroxene + orthopyroxene + quartz occurs somewhere above $700^{\circ} \mathrm{C}$ at $2 \mathrm{kbar}$.

Choudhuri and Winkler (1967) used starting materials that would approximate the composition of "ultrabasic" rocks (chlo- rite + talc + tremolite + quartz; $\left.\mathrm{Mg} /(\mathrm{Mg}+\mathrm{Fe})_{\text {rock }}=0.84\right)$. In this case the assemblage chlorite + talc + tremolite + quartz reacted to form the assemblage hornblende + anthophyllite + anorthite $+\mathrm{H}_{2} \mathrm{O}$ near $540^{\circ} \mathrm{C}$ at $1 \mathrm{kbar}\left(525^{\circ} \mathrm{C}\right.$ at $\left.0.5 \mathrm{kbar}\right)$. Hornblende was dehydrated to enstatite + diopside $+\mathrm{H}_{2} \mathrm{O}$ near $750^{\circ} \mathrm{C}$ at $1 \mathrm{kbar}\left(700^{\circ} \mathrm{C}\right.$ at $\left.1 \mathrm{kbar}\right)$. Spear (1981) used tholeiitic basalt as starting material in experiments intended to characterize amphibole breakdown at temperatures between $500^{\circ}$ and $900^{\circ} \mathrm{C}$ and pressures between 0.4 and $5 \mathrm{kbar}$. The upper stability limit of hornblende, as determined by those experiments, is plotted in Figure 4 as curve 10. At $1 \mathrm{kbar}$, hornblende breaks down to clinopyroxene + orthopyroxene + olivine + plagioclase + ilmenite near $925^{\circ} \mathrm{C}$. Clinopyroxene was not found in run products below $750^{\circ} \mathrm{C}$ at $1 \mathrm{kbar}$ (see curve 10; Fig. 4).

Spear (1981) summarized his experimental results by estimating that the incipient thermal breakdown of amphibole in rocks of basaltic composition, where $\mathrm{P}$ (fluid) $=\mathrm{P}$ (total), occurs between $750^{\circ}$ and $800^{\circ} \mathrm{C}$. He further cautioned that these temperatures are clearly dependent on the bulk composition of the rocks; quartz saturation and higher bulk-rock Fe/Mg lower the reaction temperatures (Spear, 1981).

The lower $\mathrm{Si}$ and higher $\mathrm{Mg}$ in the whole-rock compositions of the ultramafic Galicia margin samples, as compared to tholeiitic basalt, would probably result in higher reaction temperatures than those shown as curve 10 on Figure 4. Furthermore, it is suggested that $\mathrm{P}\left(\mathrm{H}_{2} \mathrm{O}\right)=\mathrm{P}($ total $)$ is a reasonable assumption during hydration reactions. Consequently, curve 10 suggests a minimum estimate of the temperature of hydration for the Galicia margin samples.

\section{Coexisting Tremolite + Hornblende}

Based on the mineral relationships indicated on the calcic amphibole solvus diagram (Fig. 3), the Aliv compositions of coexisting tremolite and hornblende or tremolite and chlorite can be used to indicate the temperature of their formation. Pyroxene is assumed to have formed at temperatures above the pyroxene breakdown line, and single calcic amphiboles of intermediate $\mathrm{Al}^{\text {iv }}$ formed above the solvus.

The crest of the solvus and the chlorite-in reaction are plotted as vertical lines (curves 11 and 12, respectively) on Figure 4. These vertical lines suggest no pressure dependence on the reaction temperature; evidence exists that suggests both positive and negative $\mathrm{dP} / \mathrm{dT}$ slopes, but no consensus exists at this time. A maximum temperature of $600^{\circ} \mathrm{C}$ and a minimum temperature of $450^{\circ} \mathrm{C}$ are suggested for the formation of the coexisting amphibole pairs.

In many samples from the Galicia margin peridotite the tremolite rims on clinopyroxene have low Al contents and plot in the single amphibole tremolite/actinolite field (Fig. 3); these tremolites contain very little information about the temperature of their formation. Other samples have textures suggesting complete amphibole replacement of clinopyroxene. In these samples there is often a range of $\mathrm{Al}^{\mathrm{iv}}$ values in the amphiboles.

Table 4. Reactions and estimated temperatures for reaction curves plotted on Figure 4.

\begin{tabular}{|c|c|c|c|}
\hline Curve & Reaction & $\underset{\left({ }^{\circ} \mathrm{C}\right)}{\operatorname{Maximum} \mathrm{T}^{\mathrm{a}}}$ & Reference \\
\hline 10 & $\mathrm{HBD}=\mathrm{CPX}+\mathrm{PLAG}+\mathrm{OLIV}+\mathrm{ILM}+\mathrm{H}_{2} \mathrm{O}$ & 925 & Spear, 1981 \\
\hline 13 & $3 \mathrm{OPX}+\mathrm{SiO}_{2}+\mathrm{H}_{2} \mathrm{O}=$ TALC & 725 & Hemley et al., 1977b \\
\hline 11 & Lower limit of supersolvus tremolite & 600 & Robinson et al., 1981 \\
\hline 14 & $\mathrm{CPX}+\mathrm{MgO}+\mathrm{CO}_{2}+\mathrm{H}_{2} \mathrm{O}=\mathrm{TREM}+2 \mathrm{CALC}$ & 520 & $\begin{array}{l}\text { Trommsdorff and Evans, } \\
1977\end{array}$ \\
\hline 12 & Lower limit of actinolite + hornblende stability & 450 & Robinson et al., 1981 \\
\hline 9 & $\mathrm{OLIV}+\mathrm{SiO}_{2}+2 \mathrm{H}_{2} \mathrm{O}=\mathrm{SERP}$ & 375 & Hemley et al., 1977a \\
\hline
\end{tabular}

at 1 kbar. 


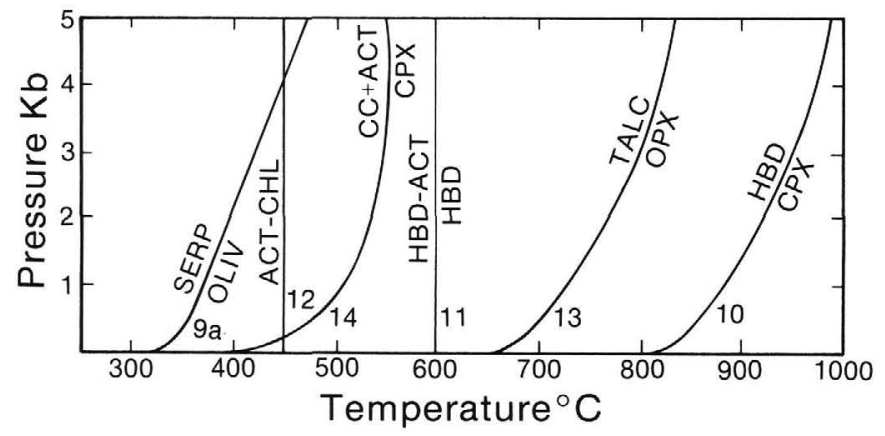

Figure 4. Pressure-temperature diagram showing experimental curves for various reactions discussed in the text. The curves, from right to left, are numbered to correspond with the equation numbers in the text: (10) $\mathrm{HBD}=\mathrm{CPX}+\mathrm{PLAG}+\mathrm{OLIV}+\mathrm{ILM}+\mathrm{H}_{2} \mathrm{O}$; (13) $3 \mathrm{OPX}+\mathrm{SiO}_{2}$ $+\mathrm{H}_{2} \mathrm{O}=$ TALC; (11) lower limit of supersolvus tremolite; (14) CPX $+\mathrm{MgO}+\mathrm{CO}_{2}+\mathrm{H}_{2} \mathrm{O}=$ TREM + 2CALC; (12) lower limit of actinolite + hornblende stability; (9a) OLIV $+\mathrm{SiO}_{2}+2 \mathrm{H}_{2} \mathrm{O}=$ SERP. References for these reactions are in Table 4.

\section{Coexisting Tremolite + Chlorite}

The experimental work of Liou et al. (1974) shows the transition from greenschist to amphibolite assemblages (chlorite out) at $450^{\circ}$ to $525^{\circ} \mathrm{C}$ (between 1 and $5 \mathrm{kbar}$ ) in rocks of basaltic composition. The effect of increasing $X_{\mathrm{Mg}}$ should be to raise these temperatures, although if $\mathrm{P}\left(\mathrm{H}_{2} \mathrm{O}\right)<\mathrm{P}$ (total), the temperatures will be lower. The chlorite-in boundary has tentatively been placed at $450^{\circ} \mathrm{C}$ (curve 12; Fig. 4), with no pressure dependence. Chlorite appears stable in geothermal systems to temperatures as low as $230^{\circ} \mathrm{C}$ (Ragnarsdottir et al., 1984). No lower chloriteout boundary is indicated on Figure 4 .

\section{Calcite Reactions}

The isotopic data of Evans and Baltuck (this volume) and Agrinier et al. (this volume) suggest that the calcite in the Galicia margin samples formed at deep-sea temperatures. As most of the analyses are whole-rock- or whole-vein-type analyses, it is possible that information about particular kinds of calcite has not been recorded (i.e., the values of the calcite replacing pyroxene cannot be distinguished from later vein or matrix calcite). It is also possible that some of this late calcite is replacing an earlier calcite that formed at higher temperatures.

\section{Orthopyroxene and Olivine Reactions}

Both orthopyroxene and olivine hydration can be discussed in terms of the experimental work in the system $\mathrm{MgO}-\mathrm{SiO}_{2}$ $\mathrm{H}_{2} \mathrm{O}$. Figure 5 is a diagram summarizing the experimental work of Hemley et al. (1977a, 1977b). The phase relations of various minerals are plotted relative to the activity of $\mathrm{SiO}_{2}$ and the temperature of alteration.

The hydration of olivine to serpentine is ubiquitous in oceanic ultramafic rocks. Experimental studies of the hydration of olivine to serpentine + brucite by Wegner and Ernst (1983) suggest that serpentinization is likely to be more constrained by the supply of water to the system than by the temperature and pressure of reaction. Studies of the waters in partially serpentinized Alpine-type ultramafic rocks suggest that serpentinization can occur at what are essentially surface temperatures (Barnes and O'Neil, 1969). The results of experimental hydration of olivine to chrysotile by Hemley et al. (1977a) are plotted as curve 9a on Figure 4. The serpentinization of olivine occurred in the temperature range $350^{\circ}$ to $500^{\circ} \mathrm{C}$, at pressures between 0.5 and 1 kbar. As those experiments were done at $\mathrm{X}_{\mathrm{Mg}}=1$ and $\mathrm{P}\left(\mathrm{H}_{2} \mathrm{O}\right)$ $=\mathrm{P}$ (total), these temperatures are necessarily maximum temperatures. Brucite and periclase have not been observed, sug-

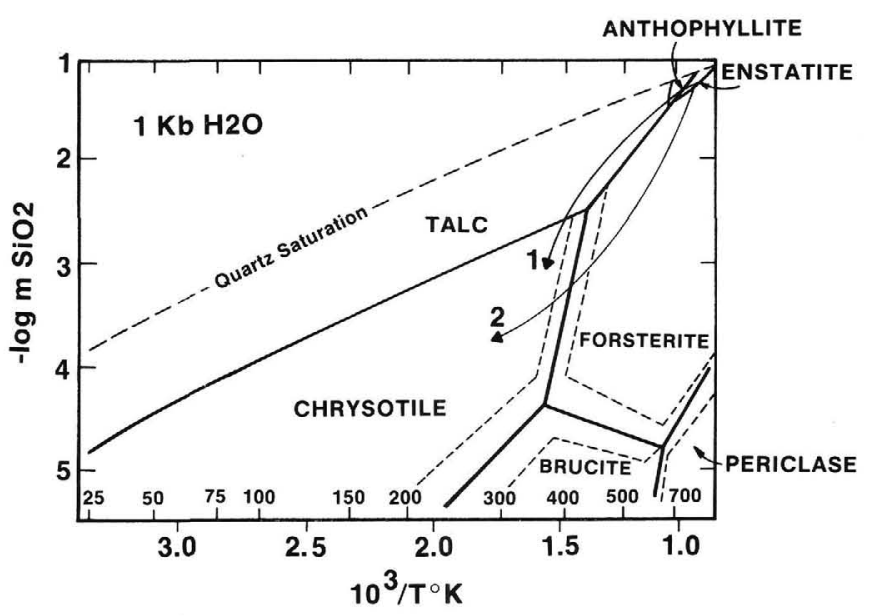

Figure 5. $-\mathrm{Log} \mathrm{m}\left(\mathrm{SiO}_{2}\right)$ vs. $10^{3} / \mathrm{T}$ diagram for the phase relations among the various Mg-silicates. Diagram is a composite of figure 2 in Hemley et al. (1977a) and figure 2 in Hemley et al. (1977b). Arrows represent a possible $\mathrm{T}-\mathrm{m}\left(\mathrm{SiO}_{2}\right)$ path for the rock, as discussed in the text.

gesting that the initial serpentinization of olivine occurred while $-\log \mathrm{m}\left(\mathrm{SiO}_{2}\right)$ in the rock was greater than 4.5 (Fig. 5). At higher activities of $\mathrm{SiO}_{2}$ the reaction temperatures are slightly higher (Fig. 5).

The hydration of enstatite to serpentine is more problematic. The experimental results suggest that enstatite + quartz $+\mathrm{H}_{2} \mathrm{O}$ will react to form anthophyllite (e.g., Hemley et al., 1977a; Greenwood, 1963, 1971; Johannes, 1966; Kitahara and Kennedy, 1966), although most workers concede that anthophyllite is notoriously difficult to crystallize. Hemley et al. (1977a) included reaction curves for enstatite hydrating to talc (the anthophyllite field is completely overstepped).

Based on Hemley et al. (1977a, 1977b), it is possible to suggest two reaction paths such that enstatite is replaced by serpentine. These are shown as arrows on Figure 5. Path 1 moves through both the anthophyllite and talc fields before reaching the chrysotile field. The temperature at which chrysotile is ultimately formed cannot really be determined $\left(25^{\circ} \mathrm{C}<\mathrm{T}<\right.$ $\left.400^{\circ} \mathrm{C}\right)$. Path 2 moves into the forsterite field $\left(\mathrm{T}>400^{\circ} \mathrm{C}\right)$ and then into the chrysotile field $\left(\mathrm{T}<400^{\circ} \mathrm{C}\right)$. Because there is no relict talc or anthophyllite in the samples, whereas forsterite is present, it is tempting to suggest that path 2 is more likely than path 1. Curve 9a (Fig. 4) is suggested as a minimum temperature estimate for the start of alteration of enstatite to serpentine.

\section{Carbonate Reactions}

It should be noted that as the activity of $\mathrm{CO}_{2}$ increases $\left(\mathrm{P}\left(\mathrm{H}_{2} \mathrm{O}\right)<\mathrm{P}(\right.$ total $\left.)\right)$, the reaction temperatures in the previously described system will appear to decrease (e.g., Evans and Trommsdorff, 1970, 1974). And, despite the pervasive presence of calcite, the absence of dolomite in any of the Galicia margin samples suggests that (1) $\mathrm{X}_{\mathrm{CO}_{2}}$ in the fluid was less than 0.05 or (2) the formation of calcite took place at temperatures above $500^{\circ} \mathrm{C}$ (Trommsdorff and Evans, 1977). Curve 14 on Figure 4 represents the maximum temperature of the alteration of clinopyroxene to calcite, based on the petrogenetic grids suggested by Trommsdorff (1972).

\section{FLUID COMPOSITIONS}

The alteration mineralogy, petrology, and phase chemistry of the Galicia margin samples indicate that these rocks have undergone an episodic hydration. No direct evidence of the composition of the fluid responsible, such as fluid inclusions, is avail- 
able. However, the stable isotopic evidence presented by Evans and Baltuck (this volume) and Agrinier et al. (this volume) suggests that the late-stage fluids were seawater.

Although the results of several excellent studies in which the composition of seawater reacting with basalt and the resultant basalt mineralogies have been calculated are available in the literature (e.g., Reed, 1983; Ragnarsdottir et al., 1984), these studies assume that the seawater reacts with the basalt at $\mathrm{T}<300^{\circ} \mathrm{C}$. Fluid calculations at higher temperatures indicate that there is a dramatic change in the behavior of metals complexing in the fluids at temperatures above $350^{\circ} \mathrm{C}$ (Kimball and Spear, 1984).

The reaction paths shown in Figure 5 suggest that at decreased alteration temperatures the activity of $\mathrm{SiO}_{2}$ (in the rock) also decreased. This is consistent with the reaction space calculations illustrated in Figure 2. The high-temperature alterations (e.g., Fig. 2B) produce only $6 \%$ to $15 \%$ of the $\mathrm{SiO}_{2}$ produced during the low-temperature reactions (Figs. 2C and 2D).

Further inspection of the reaction space diagrams (compare Fig. 2B to Figs. 2C and 2D) shows that at high temperatures the reactions are releasing $\mathrm{FeO}$ and minor $\mathrm{SiO}_{2}$ and $\mathrm{AlO}_{3 / 2}$ to the fluid and taking $\mathrm{MgO}$ from the fluid, but at low temperatures the reactions release $\mathrm{MgO}$ and $\mathrm{SiO}_{2}$ to the fluid and take $\mathrm{FeO}$ from the fluid. The relative abundance of $\mathrm{CaO}$ in the high-temperature fluid as compared to the low-temperature fluid cannot be examined because no calculations were made involving $\mathrm{CaO}$ at low temperatures. The abundance of late, low-temperature calcite suggests, however, that $\mathrm{CaO}$ was present in the late fluids.

The relative abundances of $\mathrm{Fe}$ and $\mathrm{Mg}$ in the fluids are consistent with the experimental work of Janecky (1982) in which harzburgite was reacted with seawater in several experiments at $350^{\circ} \mathrm{C}$. The initial reaction progress calculations indicate that after an initial increase in $\mathrm{Fe}^{2+}$ in solution, $\mathrm{Fe}^{2+}$ will decrease (with an assumed concomitant rise in $\mathrm{Fe}^{2+}$ in the rock; Janecky, 1982). The reaction space calculations suggest that at high temperatures moderate amounts of $\mathrm{FeO}$ were released to the fluid and at low temperatures $\mathrm{FeO}$ was taken from the fluid and added to the rock.

\section{ALTERATION MECHANISMS}

\section{Introduction}

Altered abyssal ultramafic rocks are fairly common. Any model used to describe the mechanism of alteration in these samples must also consider the mechanisms of emplacement of these materials, originally from the mantle, to the seafloor, as well as considering the alteration sequence, reaction textures, and the fact that alteration temperatures (and the composition of the altering fluid) change with time.

Work concentrating on the igneous petrology and original chemistry of the Galicia margin samples suggests that these peridotites were derived from the suboceanic upper mantle (Evans and Girardeau, this volume; Girardeau et al., this volume). These peridotites are less depleted in magmaphilic constituents than other samples of peridotite from the North Atlantic Basin, which is consistent with their tectonic setting at the boundary of the oceanic and continental crust. Evans and Girardeau (this volume) further suggest that this chemistry indicates that the peridotite was emplaced to crustal level and exposed on the seafloor prior to the onset of seafloor spreading. This uplift occurred beneath the thinned continental crust during rifting. The primary igneous mineralogy and geochemistry indicate that the last igneous equilibration of the peridotite was at temperatures about $900^{\circ}-1100^{\circ} \mathrm{C}$ and at pressures near 9 kbar (Evans and Girardeau, this volume; Girardeau et al., this volume).

\section{Alteration of Galicia Margin Peridotite}

One possible explanation for the observations we have made about alteration in the Galicia margin samples is that the ultramafic rocks were emplaced at the surface in such a way that they did not have time to cool before reaching shallow crustal levels. In this case, the ultramafic rocks would still have been hot, and fluid circulating at shallow depths in the crust could alter the rocks at high temperatures (and low pressures). As the ultramafic block cooled, the alteration temperatures would decrease (at constant pressure), producing the overprint textures observed.

Another possible mechanism for the alteration of the Galicia margin samples involves the magma chambers associated with rifting. These magma chambers are present at shallow levels beneath the ridge axes (e.g., Sleep, 1975). The mantle material could be altered at fairly shallow depths by fluids heated by a proximal magma chamber. The altered ultramafics would later be faulted to the surface (as in, for example, the OTTER 1984; Francheteau et al., 1976; Bonatti and Honnorez, 1976), continue to be altered, probably by seawater, and thus develop the very late, low-temperature alteration textures. However, there is no direct evidence that a magma chamber existed at this stage of rifting.

The brittle deformation of some of the high-temperature alteration minerals suggests a third scenario. While the ultramafics were still at depth they could have been altered by circulating fluids at high temperatures. The circulation cells suggested by this model would have to be fairly deep to produce the hightemperature alterations. As the ultramafic rocks were moved toward the surface, the alteration temperatures would decrease. Early-formed alteration minerals were deformed during uplift and subsequently overprinted by lower temperature episodic alteration.

These models are by no means exhaustive or mutually exclusive. It is quite possible that some of the early, high-temperature alteration took place at depth and some took place after emplacement. The absence of intermediate temperature alteration textures may be indicative of rapid cooling. For example, alteration of clinopyroxene at very high temperatures $\left(>850^{\circ} \mathrm{C}\right)$ followed by uplift to the surface and consequent rapid cooling is consistent with the brittle deformation of the clinopyroxenes, orthopyroxenes, and amphiboles as well as the lack of any hightemperature hydration of orthopyroxene (the orthopyroxene to amphibole reaction occurs around $800^{\circ} \mathrm{C}$ ). Alternatively, the rocks may have been exposed to intermediate temperatures and, for some reason, were overprinted selectively. Any of these models can be modified to be consistent with the tectonic scenario suggested by the igneous textures and chemistries.

\section{CONCLUSIONS}

Mineral phases, compositions, and textures in the peridotite samples drilled from the Galicia margin indicate that these rocks began interaction with hydrothermal fluids at elevated temperatures. Alteration of clinopyroxene could have begun at temperatures as high as $925^{\circ} \mathrm{C}$ and certainly began at temperatures above $600^{\circ} \mathrm{C}$. The last calcite veins probably formed at deep-sea temperatures. None of these hydration reactions can be used reliably for pressure, and hence depth, estimates.

Several models for the formation of the alteration mineralogies are proposed in light of these observations and the conclusions of Evans and Girardeau (this volume) and Girardeau et al. (this volume) that these peridotites were emplaced to shallow levels of the crust during incipient rifting of the ocean basin. The brittle cracking of the amphiboles replacing clinopyroxene suggests that the amphiboles formed before the peridotite was 
emplaced at shallow crustal levels. Subsequent alterations appear to have occurred at significantly lower temperatures, suggesting that the peridotite body cooled fairly quickly after emplacement.

\section{ACKNOWLEDGMENTS}

This manuscript was improved by the comments of G. Boillot, J. C. Cheney, and W. G. Ernst.

\section{REFERENCES}

Aumento, F., and Loubat, H., 1971. The Mid-Atlantic Ridge near $45^{\circ} \mathrm{N}$. XVI. Serpentinized ultramafic intrusions. Can. J. Earth Sci., 8:631663.

Barnes, I., and O'Neil, J. R., 1969. The relationship between fluids in some fresh alpine-type ultramafics and possible modern serpentinization, western United States. Geol. Soc. Am. Bull., 80:1947-1960.

Boillot, G., Winterer, E. L., et al., 1987. Proc. ODP, Init. Repts., 103: College Station, TX (Ocean Drilling Program).

Bonatti, E., and Honnorez, J., 1976. Sections of the Earth's crust in equatorial Atlantic. J. Geophys. Res., 81:4104-4116.

Boyd, F. R., 1959. Hydrothermal investigations of the amphiboles. In Abelson, P. H. (Ed.), Researches in Geochemistry: New York (Wiley), 377-396.

Brady, J. B., 1974. Coexisting actinolite and hornblende from west-central New Hampshire. Am. Mineral., 59:529-535.

Burnham, C. W., Holloway, J. R., and Davis, N. F., 1969. Thermodynamic properties of water to $1000^{\circ} \mathrm{C}$ and 10,000 bars. Spec. Pap. Geol. Soc. Am., 132.

Cameron, K. L., 1975. An experimental study of actinolite-cummingtonite phase relations with notes on the synthesis of Fe-rich anthophyllite. Am. Mineral., 60:375-391.

Choudhuri, A., and Winkler, H.G.F., 1967. Anthophyllit und hornblend in einigen metamorphen reaktionen. Contrib. Mineral. Petrol., 14: 367-374.

Cooper, A. F., and Lovering, J. F., 1970. Greenschist amphiboles from Haast River, New Zealand. Contrib. Mineral. Petrol., 44:45-55.

Dick, H.J.B., and Bullen, T., 1984. Chromian spinel as a petrogenetic indicator in abyssal and alpine-type peridotites and spatially associated lavas. Contrib. Mineral. Petrol., 86:54-76.

Evans, B. W., and Trommsdorff, V., 1970. Regional metamorphism of ultramafic rocks in the Central Alps: parageneses in the system CaO-MgO-SiO ${ }_{2}-\mathrm{H}_{2} \mathrm{O}$. Schweiz. Mineral. Petrogr. Mitt., 50:481492.

1974. Stability of enstatite + talc, and $\mathrm{CO}_{2}$ metasomatism of meta-peridotite, Val d'Efra, Lepontine Alps. Am. J. Sci., 274 274-296.

Ferry, J. M., 1983. Application of the reaction progress variable in metamorphic petrology. J. Petrol., 24:343-376.

Francheteau, J., Choukrone, P., Hekinian, R., LePichon, X., and Needham, D., 1976. Oceanic fracture zones do not provide deep sections into the crust. Can. J. Earth Sci., 13:1223-1235.

Graham, C. M., 1974. Metabasite amphiboles of the Scottish Dalradian. Contrib. Mineral. Petrol., 47:165-185.

Grapes, R. H., and Graham, C. M., 1978. The actinolite-hornblende series in metabasites and the so-called miscibility gap: a review. Lithos, 11:88-97.

Greenwood, H. J., 1963. Synthesis and stability of anthophyllite. J. Petrol., 4:317-351.

1971. Anthophyllite. Corrections and comments on its stability. Am. J. Sci., 270:151-154.

Helgeson, H. C., Delany, J. M., Nesbitt, H. W., and Bird, D. K., 1978. Summary and critique of the thermodynamic properties of rockforming minerals. Am. J. Sci., 278A: 1-299.

Hemley, J. J., Montoya, J. W., Christ, C. L., and Hostetler, P. B. 1977a. Mineral equilibria in the $\mathrm{MgO}-\mathrm{SiO}_{2}-\mathrm{H}_{2} \mathrm{O}$ system: I. Talcchrysotile-forsterite-brucite stability relations. Am. J. Sci., 277:353383.

Hemley, J. J., Montoya, J. W., Shaw, D. R., and Luce, R. W., 1977b. Mineral equilibria in the $\mathrm{MgO}-\mathrm{SiO}_{2}-\mathrm{H}_{2} \mathrm{O}$ system: II. Talc-antigoriteforsterite-anthophyllite-enstatite stability relations and some geologic implications in the system. Am. J. Sci., 277:353-383.

Janecky, D. R., 1982. Serpentinization of peridotite within the oceanic crust: experimental and theoretical investigations of seawater-peridotite interaction at $200^{\circ} \mathrm{C}$ and $300^{\circ} \mathrm{C}, 500$ bars [Ph.D. dissert.]. Univ. of Minnesota.
Jasmund, K., and Schafer, R., 1972. Experimetalle bestimmung der P-T stabilutatsbereiche in der mischkistallreihe tremolittschermakite. Contrib. Mineral. Petrol., 56:1-25.

Johannes, W., 1966. An experimental investigation of the system MgO$\mathrm{SiO}_{2}-\mathrm{H}_{2} \mathrm{O}-\mathrm{CO}_{2}$. Am. J. Sci., 267:1083-1104.

Kimball, K. L., 1985. Chemical zoning in spinels from hydrothermally altered abyssal ultramafics: Islas Orcadas and Shaka fracture zones. Eos, Trans. Am. Geophys. Union, 66:432. (Abstract)

1988. High temperature hydrothermal alteration of ultramafic rocks in the Josephine ophiolite, California. J. Geophys. Res., 93:4675-4687.

Kimball, K. L., in press. Effects of hydrothermal alteration on the compositions of chromite spinels. Contrib. Mineral. Petrol.

Kimball, K. L., Gerlach, D. G., and Spear, F. S., 1984. Calculated models of $\mathrm{Mg}-\mathrm{Fe}-\mathrm{SiO}_{2}-\mathrm{Cl}-\mathrm{H}_{2} \mathrm{O}$ fluid evolution and variable ${ }^{87} \mathrm{Sr} /$ ${ }^{86} \mathrm{Sr}$ in alteration minerals: Islas Orcadas Fracture Zone. Eos, Trans. Am. Geophys. Union, 65:1124. (Abstract)

Kimball, K. L., and Spear, F. S., 1984. Compositional constraints on hydrothermal alteration fluids: Islas Orcadas Fracture Zone. Eos, Trans. Am. Geophys. Union, 65:228. (Abstract)

Kimball, K. L., Spear, F. S., and Dick, H.J.B., 1985. High temperature alteration of abyssal ultramafics from the Islas Orcadas Fracture Zone, South Atlantic. Contrib. Mineral. Petrol., 91:307-320.

Kitahara, S., and Kennedy, G. C., 1967. The calculated equilibrium curves for some reactions in the system $\mathrm{MgO}-\mathrm{SiO}_{2}-\mathrm{H}_{2} \mathrm{O}$ at pressures up to 30 kilobars. Am. J. Sci., 265:211-217.

Klein, C., 1969. Two-amphibole assemblages in the system actinolitehornblende-glaucophane. Am. Mineral., 54:212-237.

Liou, J. G., Kuniyoshi, S., and Ito, K., 1974. Experimental studies of the phase relations between greenschist and amphibolite in a basaltic system. Am. J. Sci., 274:613-632.

Misch, P., and Rice, J. M., 1975. Miscibility of tremolite and hornblende in progressive Skagit metamorphic suite, North Cascades, Washington. J. Petrol., 16:1-21.

Oba, T., 1980. Phase relations in the tremolite-pargasite join. Contrib. Mineral. Petrol., 71:247-256.

Ragnarsdottir, K. V., Walther, J. V., and Arnorsson, S., 1984. Description and interpretation of the composition of fluid and alteration mineralogy in the geothermal system at Svartsengi, Iceland. Geochim. Cosmochim. Acta, 48:1535-1553.

Reed, M. N., 1983. Seawater-basalt reaction and the origin of greenstones and related ore deposits. Econ. Geol., 78:466-485.

Robinson, P., Spear, F. S., Schumaker, J. C., Laird, J., Klein, C., Evans, B. W., and Doolan, B. W., 1981. Phase relations of metamorphic amphiboles: natural occurrence and theory. In Veblen, D. (Ed.), Amphiboles and other Hydrous Pyriboles: Rev. Mineral., 9B:1-228.

Sampson, G. A., and Fawcett, J. J., 1977. Coexisting amphiboles from the Hastings region of southeastern Ontario. Can. Mineral., 15:283296.

Shipboard Scientific Party, 1987. Site 637. In Boillot, G., Winterer, E. L., et al., Proc. ODP, Init. Repts., 103: College Station, TX (Ocean Drilling Program), 123-219.

Sleep, N. H., 1975. Formation of oceanic crust: some thermal constraints. J. Geophys. Res., 80:4037-4042.

Spear, F. S., 1981. An experimental study of hornblende stability and compositional variability in amphibolite. Am. J. Sci., 281:697-734.

Spear, F. S., and Kimball, K. L., 1985. RECAMP-A FORTRAN IV program for estimating $\mathrm{Fe}^{3+}$ contents in amphiboles. Comput. Geosci., 10:317-325.

Tagiri, M. 1977. Fe-Mg partition and miscibility gap between coexisting calcic amphiboles from the Southern Abukuma Plateau Japan. Contrib. Mineral. Petrol., 62:271-281.

Trommsdorff, V., 1972. Change in T-X during metamorphism of siliceous dolomitic rocks of the Central Alps. Schweiz. Mineral. Petrogr. Mitt., 52:567-571.

Trommsdorff, V., and Evans, B. W., 1977. Antigorite-ophicarbonates: phase relations in a portion of the system $\mathrm{CaO}-\mathrm{MgO}-\mathrm{SiO}_{2}-\mathrm{H}_{2} \mathrm{O}-$ $\mathrm{CO}_{2}$. Contrib. Mineral. Petrol., 60:39-56.

Wegner, W. W., and Ernst, W. G., 1983. Experimentally determined hydration and dehydration reaction rates in the system $\mathrm{MgO}^{-} \mathrm{SiO}_{2}$ $\mathrm{H}_{2}$ O. Am. J. Sci., 283A:151-180.

Date of initial receipt: 16 March 1987

Date of acceptance: 28 October 1987

Ms 103B-140 